E-JURNAL EKONOMI DAN BISNIS UNIVERSITAS UDAYANA
Available online at https://ojs.unud.ac.id/index.php/EEB/index
Vol. 10 No. 02, February 2021, pages: 53 - 60
e-ISSN: 2337-3067

\title{
THE EFFECT OF LIQUIDITY, COMPANY SIZE, AND INDEPENDENT COMMISSIONER ON TAX AGGRESSIVENESS
}

\author{
Lydia Nur Athifah ${ }^{1}$, Endang Mahpudin ${ }^{2}$
}

Article history:

Submitted: 12 November 2020

Revised: 14 November 2021

Accepted: 3 Desember 2021

\section{Keywords:}

Liquidity;

Company Size;

Independent Commissioner;
Kata Kunci:

Liquidity;

Ukuran Perusahaan;

Independent Commissioner;

\section{Koresponding:}

Universitas Singaperbangsa
Karawang, Jawa Barat,
Indonesial
Email:
Lydia.nurathifah16167@student
.unsika.ac.id

Each country has income to finance all government activities used to build infrastructure and public facilities for the community. One of them is sourced from tax revenue. Taxes are the main source of income for the state, one of which is the tax receipts that are deposited by business actors or companies. For the government, if the greater the tax paid by the company, the greater the state's revenue from the tax sector. However, it is of different interest for the company because taxes become a burden that can reduce the income the company receives each year. Of course this is contrary to the company's goal of earning as much income as possible and incurring minimal costs. The purpose of this study was to determine the effect of liquidity, company size, and independent commissioners on tax aggressiveness. This research was conducted at food and beverage subsector consumer goods companies listed on the IDX in the 2014-2018 period. The data analysis technique used is multiple linear regression. Based on the research results, it is known that partially liquidity has no significant effect on tax aggressiveness, firm size has a significant effect on tax aggressiveness, and independent commissioners do not have a significant effect on tax aggressiveness.

Abstrak
Setiap negara memiliki pendapatan untuk membiayai semua
kegiatan pemerintah yang digunakan untuk membangun infrastruktur dan
fasilitas umum bagi masyarakat. Salah satunya bersumber dari penerimaan
pajak. Pajak merupakan sumber utama pendapatan negara, salah satunya
penerimaan pajak yang disetorkan oleh pelaku usaha atau perusahaan. Bagi
pemerintah, jika semakin besar pajak yang dibayarkan perusahaan maka
semakin besar pula penerimaan negara dari sektor perpajakan. Namun
berbeda kepentingannya bagi perusahaan karena pajak menjadi beban yang
dapat mengurangi pendapatan yang diterima perusahaan setiap tahunnya.
Tentunya hal ini bertentangan dengan tujuan perusahaan untuk memperoleh
pendapatan sebanyak mungkin dan biaya yang dikeluarkan seminimal
mungkin. Tujuan penelitian ini adalah untuk mengetahui pengaruh
likuiditas, ukuran perusahaan, dan komisaris independen terhadap
agresivitas pajak. Penelitian ini dilakukan pada perusahaan barang
konsumsi subsektor makanan dan minuman yang terdaftar di BEI periode
2014-2018. Teknik analisis data yang digunakan adalah regresi linier
berganda. Berdasarkan hasil penelitian diketahui bahwa secara parsial
likuiditas tidak berpengaruh signifikan terhadap agresivitas pajak, ukuran
perusahaan berpengaruh signifikan terhadap agresivitas pajak, dan
komisaris independen tidak berpengaruh signifikan terhadap agresivitas
pajak.




\section{INTRODUCTION}

Each country has income to finance all government activities used to build infrastructure and public facilities for the community. One of them is sourced from tax revenue. Taxes are the main source of income for the state, one of which is the tax receipts that are deposited by business actors or companies. For the government, if the greater the tax paid by the company, the greater the state's revenue from the tax sector. However, it is of different interest for the company because taxes become a burden that can reduce the income the company receives each year. Of course this is contrary to the company's goal of earning as much income as possible and incurring minimal costs. This difference of interest is what causes companies to look for other alternatives to reduce the tax that must be paid to the state by taking tax aggressive action by exploiting the gaps in tax regulations.

According to Lanis and Richardson in Dewi \& Cynthia (2018), tax aggressiveness is all the efforts made by management to reduce the amount of tax that must be paid by companies. If more and more tax loopholes are used by companies, the company is considered to be more aggressive in reducing its tax burden. And, there are several factors that can affect the tax aggressiveness carried out by companies, one of which is liquidity. Tax is a company's short-term obligation, and to see the company's ability to carry out its short-term obligations, namely from the liquidity ratio. If the company has a high liquidity ratio, then the company is in a smooth cash flow condition. The condition of companies with high liquidity ratios is considered able to meet short-term obligations, so companies are considered not reluctant to pay taxes. Previous studies conducted by Fadli (2016), Rio (2018), and Chaidir \& Rifkhan (2019) showed the results that liquidity had a significant effect on tax aggressiveness. However, different from the results of research conducted by Yogiswari and Samantha (2017), Nurjanah et al., (2018), and Ariani \& Hasymi (2018) which show the results that liquidity has no significant effect on tax aggressiveness.

In addition to liquidity, company size is also considered capable of influencing tax aggressiveness. Large-scale companies are considered to have the ability, resources, and more experience in making efforts to minimize the tax burden borne by the company. Efforts to minimize this tax burden are often called tax planning (Rori, 2013 in Mahpudin, 2017). Based on previous research conducted by Putri et al., (2018), Nurjanah et al., (2018), and Sri \& Setyadi (2019) illustrate the results that company size has a significant effect on tax aggressiveness. Contrary to the research results of Ariani \& Hasymi (2018), Chaidir \&Rifkhan (2019), and Maulana (2020) which showed the results that company size had no significant effect on tax aggressiveness.

Zemzem \& Ftouhi (2013) in Sufia \& Riswandari (2018) which states that independent commissioners can increase the ability of the board to effectively monitor management in situations marked by problems arising from the separation of ownership, control, and can help reduce tax aggressiveness. Previous studies conducted by Subagiastra et al., (2016), Fadli (2016), and Fitriyawati (2018) showed the results that independent commissioners had a significant effect on tax aggressiveness. Another case with the results of research conducted by Nurjanah et al., (2018), Sufia \& Riswandari (2018), and Budianti et al., (2018) which stated that independent commissioners had no significant effect on tax aggressiveness.

\section{RESERCH METHOD}

This research uses quantitative methods. The population used in this study were food and beverage sub-sector consumer goods companies listed on the Indonesia Stock Exchange (IDX) in 2014-2018. In addition, this study uses a purposive sampling technique with the criteria of food and beverage sub-sector consumer goods companies listed on the Stock Exchange in 2014-2018, the company experienced profits during 2014-2018, the company used the rupiah currency, the company consistently published financial statements audited 2014-2018. So that selected 11 companies that meet the criteria to be sampled in this study. 


\section{Table 1 \\ Sample Criteria}

\begin{tabular}{clc}
\hline NO & \multicolumn{1}{c}{ CRITERIA } & TOTAL \\
\hline 1 & $\begin{array}{l}\text { Total of manufacturing companies manufacturing consumer goods sub-sector food } \\
\text { and beverage sectors listed on the Indonesia Stock Exchange (IDX) in a row during } \\
\text { the 2014-2018 period. }\end{array}$ & 18 \\
2 & Companies that did not get profits in a row during the 2014-2018 period. & $(2)$ \\
3 & $\begin{array}{l}\text { Companies that do not use rupiah. } \\
\text { Companies that did not consistently publish the audited financial statements during }\end{array}$ & 0 \\
& $\begin{array}{l}\text { To14-2018. } \\
\text { Total of Companies Selected as Samples } \\
\text { Total Review (11x5) }\end{array}$ & 11 \\
\hline
\end{tabular}

Source : Review by researcher, 2020.

The analytical method used in this study is multiple linear regression analysis which is an analysis technique to determine the effect of the independent variables on the dependent variable. In this study, multiple linear regression tests are used to test the effect of liquidity, company size, and independent commissioners on tax aggressiveness. The models in this study are :

$$
\mathrm{Y}=\mathrm{a}+\mathrm{b}_{1} \mathrm{X}_{1}+\mathrm{b}_{2} \mathrm{X}_{2}+\mathrm{b}_{3} \mathrm{X}_{3}+\mathrm{e}
$$

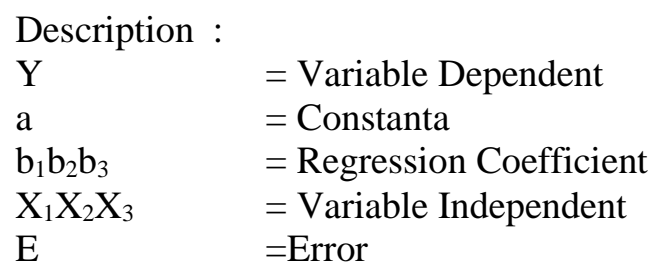

\section{RESULT AND DISCUSSION}

Table 2 shows the research on 55 samples data from the food and beverage sub sector listed on Indonesia Stock Exchange from 2014 to 2018, while the results from descriptive statistics are current Ratio has a mean of 3,13 which value is higher than the standard deviation of 2,70 (mean 3,13 $>$ standard deviation 2,70) so that it indicates fairly good results. Because the standard deviation is a reflection of a high deviation, so the spread of data shows normal results does not cause bias. As well as a minimum value of 1,07 and a maximum value of 15,82 which indicates that the company's current ratio has considerable fluctuations.

SIZE has a mean value of 15,06 and the standard deviation is 1,55 , this means the mean $15,06>$ standard deviation is 1,55 or the mean is higher than the standard deviation which indicates a fairly good result. This is because the standard deviation is a reflection of a very high deviation, which causes normal data and does not cause bias. In addition, the minimum value on SIZE is 12,71 and the maximum value is 18,39 , which means that the size of the company has fluctuations that are not too large.

PIC has a mean value of 0,37 and the standard deviation is 0,06 , this means the mean 0,37 > standard deviation is 0,06 or the mean is higher than the standard deviation which indicates a fairly good result. This is because the standard deviation is a reflection of a very high deviation, which causes normal data and does not cause bias. In addition, the minimum value on PIC is 0,33 and the maximum value is 0,50 , which means that the PIC of the company has fluctuations that are not too large. 
ETR has a mean value of 0,25 and the standard deviation is 0,04 , this means the mean 0,25 $>$ standard deviation is 0,04 or the mean is higher than the standard deviation which indicates a fairly good result. This is because the standard deviation is a reflection of a very high deviation, which causes normal data and does not cause bias. In addition, the minimum value on ETR is 0,13 and the maximum value is 0,35 , which means that the ETR of the company has fluctuations that are not too large.

Table 2

Descriptive Statistical Analysis of Each Variable

\begin{tabular}{|l|r|r|r|r|r|}
\hline & N & \multicolumn{1}{|c|}{ Minimum } & Maximum & \multicolumn{1}{|c|}{ Mean } & \multicolumn{2}{|c|}{ Std. Deviation } \\
\hline CR & 55 & 1,07 & 15,82 & 3,13 & 2,70 \\
SIZE & 55 & 12,71 & 18,39 & 15,06 & 1,55 \\
PIC & 55 &, 33 &, 50 &, 37 &, 06 \\
ETR & 55 &, 13 &, 35 &, 25 &, 04 \\
Valid N & 55 & & & & \\
(listwise) & & & & \\
\hline
\end{tabular}

Source : data processed by SPSS 22, 2020.

Table 1

Results of Normality Test

One-Sample Kolmogorov-Smirnov Test

\begin{tabular}{|ll|r|}
\hline & & \multicolumn{1}{|c|}{ Unstandardized Residual } \\
\hline $\mathrm{N}$ & & 55 \\
Normal Parameters & Mean &, 0000000 \\
& Std. Deviation &, 03480099 \\
Most Extreme Differences & Absolute &, 070 \\
& Positive &, 056 \\
& Negative &,- 070 \\
Test Statistic & &, 070 \\
Asymp. Sig. (2-tailed) & &, $200^{\mathrm{c}, \mathrm{d}}$ \\
\hline
\end{tabular}

Source : data processed by SPSS 22, 2020.

Based on the results of normality tests with Kolmogrov Smirnov showed the results of Asymp. Sig. 0,200, which means the Asymp value. Sig. > 0.05. So, it can be concluded that the data distribution in this study is normal. The results of multicollinearity test obtained by VIF values for liquidity variables, company size, and independent commissioners are 1,054, 1,243, and 1,200, so it can be concluded that these variables do not experience multicollinearity. Based on scatterplot diagram outputs are known that the points spread randomly, as well as. it can be concluded that there are no symptoms of heterokedasticity in the regression model used. Based on the results of the autocorrelation test, the Durbin Watson (DW) value does not occur autocorrelation in this study variable.

Based on the results of processing with SPSS 22, the results of the multiple linear regression analysis equation are as follows:

$$
\mathrm{ETR}=0,016+0,002 \mathrm{CR}+0,20 \mathrm{SIZE}-0,164 \mathrm{PIC}
$$

The constant in the regression model above shows the number 0,016. This figure represents the magnitude of the company's tax aggressiveness at the time of current ratio, company size, and an independent commissioner has a value of 0 . The regression coefficient for liquidity $\left(\mathrm{X}_{1}\right)$ has a positive 
value of 0,002 . This means that if current ratio has increased by one unit, the tax aggressiveness will increase by 0,002 or $2 \%$. Likewise, when liquidity decrease, the aggressiveness of corporate taxes will also decrease.

The regression coefficient for company size $\left(X_{2}\right)$ has a positive value of 0,20 . This means that if company size has increased by one unit, the tax aggressiveness will increase by 0,20 or $20 \%$. Likewise, when company size decrease, the aggressiveness of corporate taxes will also decrease. The regression coefficient for independent commissioner $\left(\mathrm{X}_{3}\right)$ has a negative value of 0,164 . This means that if the independent commissioner has decreased by one unit, the tax aggressiveness will increase by 0.164 or $16,4 \%$. Likewise, when an independent commissioner increase, tax aggressiveness will decrease.

Table 4

Result of Multiple Linear Regression Analysis

\begin{tabular}{|c|c|c|c|c|c|}
\hline \multirow[t]{2}{*}{ Model } & \multicolumn{2}{|c|}{ Unstandardized Coefficients } & $\begin{array}{c}\text { Standardized } \\
\text { Coefficients }\end{array}$ & \multirow[t]{2}{*}{$\mathrm{T}$} & \multirow[t]{2}{*}{ Sig. } \\
\hline & B & Std. Error & Beta & & \\
\hline (Constant) & ,016 &, 052 & & ,308 &, 759 \\
\hline $\mathrm{CR}$ & ,002 &, 002 &, 109 & ,967 & ,338 \\
\hline SIZE & 020 &, 003 & 687 & 5,590 & ,000 \\
\hline PIC &,- 164 & ,084 &,- 234 & $-1,937$ &, 058 \\
\hline
\end{tabular}

Source : data processed by SPSS 22, 2020.

And, based on the table 4 for $T$ test results indicate that the t-value of 0.967 means that the liquidity variable has no significant effect on tax aggressiveness. The insignificance of the variable liquidity on tax aggressiveness can be caused because the level of liquidity in the food and beverage sub-sector companies is relatively the same. This can be shown by the standard deviation of 2.70517 which is smaller when compared to the average liquidity value of the food and beverage sub-sector company which is 3.1341. In addition, the average liquidity in the range of 3.1341 illustrates that companies tend to maintain liquidity at this figure, which means that the company has the ability to pay off short-term obligations including paying taxes in accordance with applicable tax provisions, and illustrates that the cash flow conditions at food and beverage sub sector is smooth and healthy. And companies maintain the level of liquidity at a certain number then it will not affect aggressive actions taken by the company against the tax burden. so the condition of a good liquidity ratio will not make tax as a goal to minimize costs.

The results of this study are in line with the results of previous studies conducted by Yogiswari \& Samantha (2017) in manufacturing companies that show the results that liquidity has no effect on tax aggressiveness. The insignificance of the relationship between liquidity and tax aggressiveness can be caused by the level of liquidity (CR) in their samples being almost the same. Research conducted by Nurjanah et al., (2018) on agricultural and mining companies also found that liquidity had no effect on tax aggressiveness can be caused by a relatively similar level of liquidity ratio (CR). And, research from Mustika et al.,(2019) on property and real estate companies states that liquidity has no significant effect on tax aggressiveness. The insignificance of the relationship between liquidity and tax aggressiveness can be caused by the relatively similar level of liquidity ratios in their study sample.

The results of some researchers can show that the current high ratio illustrates unemployed cash considered less productive. But if the current ratio is too low, it will reduce the level of creditor confidence in the company and can result in capital loans by creditors to decline. Therefore, it is possible for companies to maintain their level of liquidity ratios at certain figures, so that the effect of liquidity ratios is not found on tax aggressiveness (Mustika et al., 2019). 
Based on the results of the test showed that company size variables have a significant influence on tax aggressiveness. The results of this study are in line with the theory put forward by Xing Liu \& Shujun Cao (2007) in Djohar \& Rifkhan (2019) which states that companies with larger sizes tend to have political power and benefit from it by influencing regulations on the taxation field so that it does not directly have a significant impact on corporate tax aggressiveness. Conformity of the results of this study with the theory proves that companies that have large total assets, large operating activities and superior quality resources will utilize existing resources to reduce the tax burden that must be paid by utilizing loopholes in legally applicable tax regulations. In addition, large scale companies tend to have the ability to do tax management, compared to small scale companies.

The results of this study support previous studies conducted by Putri et al., (2018) in mining companies which show the results that company size affects tax aggressiveness. The results of the study revealed by Nurjanah et al., (2018) in agricultural and mining companies stated that the size of the company had a significant effect on tax aggressiveness caused by the company's agriculture and mining sector having large total assets, large operating activities, and resources with superior quality will utilize existing resources to reduce the tax burden that must be paid by utilizing loopholes from legally applicable tax regulations. Research from Yuliana (2018) on manufacturing companies found the results that company size had a significant effect on tax aggressiveness. This shows that the greater the size of the company will reduce the level of tax aggressiveness and has a significant effect.

Based on the results of the $t$ test, the independent commissioner variable does not have a significant influence on tax aggressiveness. This study shows that the proportion of independent commissioners owned is considered unable to influence the tax aggressiveness that occurs in the company. That is because independent commissioners also have limitations in handling problems faced by the organization due to lack of information obtained so that independent commissioners cannot conduct a complete and independent analysis (Muntoro, 2006 in Nurjanah et al., 2018). In addition, there are also indications that independent commissioners from outside the company that are part of the company's board of commissioners do not carry out their supervisory functions properly on the company's management. And, the insignificance of the relationship between the proportion of independent directors and the level of tax aggressiveness can also be caused by the relatively equal number of independent directors in the food and beverage sub-sector companies by looking at the results of descriptive statistical analysis which shows that the standard deviation of 0.06322 is smaller than the average independent commissioner of the food and beverage sub-sector company is 0.3791 .

The results of this study are in line with previous studies conducted by Tiaras \& Wijaya (2015) on manufacturing companies which stated that independent commissioners had no significant effect on tax aggressiveness with an average proportion of $38.20 \%$ independent commissioners. This shows that the proportion of independent directors has no significant effect on the aggressiveness of internal management taxes. Azizah \& Kusmuriyanto (2016) in non-financial companies also showed the results that independent commissioners had no significant effect on tax aggressiveness. And research from Nurjanah et al., (2018) on agriculture and mining companies revealed that independent commissioners had no significant effect on tax aggressiveness. The insignificance of the relationship between the proportion of independent directors and the level of tax aggressiveness can be caused by the number of independent commissioners in agricultural and mining companies is relatively the same.

However, contrary to the results of research from Fadli (2016) on manufacturing companies which states that independent commissioners influence tax aggressiveness. This can be caused by the more number of independent commissioners owned by the company, the greater the influence to supervise management performance, thus the level of tax aggressiveness will decrease. The findings made by Fitriyawati (2018) at manufacturing companies also show the results that Independent commissioners have a significant effect on tax aggressiveness.

The simultaneous test shows that all independent variables in this study such as liquidity, company size, and independent commissioners simultaneously influence the dependent variable, namely tax aggressiveness. The results of this study are in line with the research of Tiaras \& Wijaya (2015) on manufacturing companies which state that the variables independent such as liquidity, 
company size, and independent commissioners simultaneously influence the dependent variable namely tax aggressiveness.

In addition, Nurjanah et al., (2018) findings on agricultural and mining companies also state that independent variables such as liquidity, company size, and Independent commissioners simultaneously affect the dependent variable, namely tax aggressiveness. And, Susanto et al., (2018) in manufacturing companies showed the results that independent variables such as liquidity, company size, and independent commissioners simultaneously affected the dependent variable, namely tax aggressiveness.

Table 5

Results of Coefficient Determination Test $\left(\mathbf{R}^{2}\right)$

\begin{tabular}{|l|r|r|r|r|}
\hline Model & \multicolumn{1}{|c|}{$\mathrm{R}$} & R Square & Adjusted R Square & Std. Error of the Estimate \\
\hline 1 &, $617^{\mathrm{a}}$ &, 381 &, 344 &, 03581 \\
\hline
\end{tabular}

Source : data processed by SPSS 22, 2020.

Based on table 5 we can see the magnitude of the relationship between the independent variable and the dependent variable calculated by the correlation coefficient is the value of $\mathrm{R} 0,617$. This shows a fairly strong relationship between the independent variable and the dependent variable.

Contributions of liquidity, company size, and independent commissioner variables that affect the tax aggressiveness of companies in the food and beverage sub-sector listed on the Indonesia Stock Exchange in 2014-2018 are determined by the formula CD $=\mathrm{r}^{2} \times 100 \%=0,617^{2} \times 100 \%=$ $38,1 \%$. The contribution of $38,1 \%$ to the variable aggressiveness of the tax companies in the food and beverage sub-sector listed on the Indonesia Stock Exchange in 2014-2018 is explained by the variable liquidity, company size, and independent commissioners, while the remaining $61,9 \%$ is determined by other variables cannot be explained in this study.

\section{CONCLUSION}

Based on the results of the analysis that has been done regarding the effect of Liquidity, Company Size, and Independent Commissioners on Tax Aggressiveness, it can be concluded that liquidity has no partial effect on Tax Aggressiveness. Liquidity level in the food and beverage sector companies are expected to be able to maintain their cash flows in good condition so that they can meet their short-term obligations including paying off tax debts. So companies do not need to take tax aggressiveness.

Company size partially influences Tax Aggressiveness. And, company size in the food and beverage sector companies are expected to maintain the stability of the company size and also can increase the level of company size so that the company has adequate resources to carry out legal tax planning. Independent Commissioners partially do not affect Tax Aggressiveness. Independent commissioner in the food and beverage sector companies are expected to be able to maintain or increase the size and composition of the independent board of commissioners in the company, and also increase the monitoring so that tax aggressiveness do not occur in the company. Simultaneously, Liquidity, Company Size, and Independent Commissioners influence Tax Aggressiveness

\section{REFERENCE}

Ariani, M., \& Hasymi, M. (2018). Pengaruh Profitabilitas, Likuiditas, Leverage, Size, dan Capital Intensity Ratio Terhadap Effective Tax Rate (ETR). Komunikasi Ilmiah Akuntansi dan Perpajakan, 2(2). 452-463.

Ayem, S., \& Setyadi, A. (2019). Pengaruh Profitabilitas, Ukuran Perusahaan, Komite Audit, dan Capital Intensity Terhadap Agresivitas Pajak (Studi pada Perusahaan Perbankan yang Terdaftar di BEI Periode Tahun 2013-2017). Jurnal Akuntansi Pajak Dewantara, 3(4). 228-241.

Azizah, N., \& Kusmuriyanto. (2016). The Effect of Related Party Transaction, Leverage, Commissioners and Directors Compensation on Tax Aggressiveness. Accounting Analysis Journal, 3(7). 307-316. 
Budianti, I., Nazar, M. R., \& Kurnia. (2018). Pengaruh Profitabilitas (ROA), Leverage (DER), Komisaris Independen dan Ukuran Perusahaan Terhadap Agresivitas Pajak (Studi Kasus pada Perusahaan BUMN yang Terdaftar di BEI Periode 2012-2016). e-Proceeding of Management, 6(9). 2368-2376.

Cynthia, S. P. (2018). Aggressiveness Tax in Indonesia. Jurnal Akuntansi, 5(8). 239-254.

Djohar, C., \& Rifkhan. (2019). Pengaruh Likuiditas dan Ukuran Perusahaan Terhadap Agresivitas Pajak (Studi Empiris pada Perusahaan Manufaktur yang Terdaftar di Bursa Efek Indonesia Tahun 2012-2017). Jurnal Renaissance, 7(5). 523-532.

Fadli, I. (2016). Pengaruh Likuiditas, Leverage, Komisaris Independen, Manajemen Laba, dan Kepemilikan Institusional Terhadap Agresivitas Pajak Perusahaan (Studi pada Perusahaan Manufaktur yang Terdaftar di Bursa Efek Indonesia Periode 2011-2013). JOM Fekon, 4(4). 1205-1219.

Lanis, R., \& Richardson, G. (2012). Corporate Social Responsibility and Tax Aggressiveness : an Empirical Analysis. Journal of Accounting and Public Policy, 7(2). 86-108.

Mahpudin, E. (2017). Pengaruh Perencanaa Pajak Terhadap Manajemen Laba pada Perusahaan yang Termasuk Ddalam Jakarta Islamic Index. Journal Unsika, 4(7). 389-403.

Maulana, I. A. (2020). Faktor-Faktor yang Mempengaruhi Agresivitas Pajak pada Perusahaan Properti dan Real Esate . Jurnal KRISNA : Kumpulan Riset Akuntansi, 7(2). 155-163.

Mustika, M., Sulistyowati, \& Wahyuni, E. N. (2019). Examining the Impact of Liquidity, Leverage, and Earning Management on Corporate Tax Aggressiveness in Property and Real Estate Companies on Indonesia Stock Exchange. Atlantis Press, 3(9). 97-100.

Nurjanah, I., Hanum, A. N., \& Alwiyah. (2018). Pengaruh Likuiditas, Leverage, Corporate Social Responsibility, Ukuran Perusahaa, dan Komisaris Independen Terhadap Agresivitas Pajak Badan. Prosiding Seminar Nasional Mahasiswa Unimus, 5(3). 432-438.

Putri, R., Rafki, M., \& Kurnia. (2018). Pengaruh Corporate Social Responsibility, Leverage, dan Ukuran Perusahaan Terhadap Agresivitas Pajak (Studi pada Perusahaan Sektor Pertambangan yang Terdaftar di Bursa Efek Indonesia Tahun 2014-2016). e-Proceeding of Management, 8(1). 2139-2146.

Riswandari, L. S. (2018). Pengaruh Manajemen Laba, Proporsi Komisaris Independen, Profitabilitas, Capital Intensity, dan Likuiditas Terhadap Tax Aggressiveness (Studi Empiris pada Perusahaan Manufaktur yang Terdaftar di Bursa Efek Indonesia Tahun 2012-2016). Jurnal Akuntansi Bisnis, 2(6). 140-156.

Rori, H. (2013). Analisis Penerapan Tax Planning atas Pajak Penghasilan Badan . Jurnal EMBA, 6(1). 410-418.

Setyowati, E., Titisari, K. H., \& Dewi, R. R. (2018). The Effect of Profitability, Leverage, Liquidity, and Company Size on Aggressiveness Tax the Sector Companies Consumer Goods Industry that Listed on the Indonesia Stock Exchange Year 2014-2016. The 2nd ICTESS 2018, 7(1). 374-382.

Subagiastra, K., Arizona, I. P., \& Mahaputra, I. N. (2016). Pengaruh Profitabilitas, Kepemilikan Keluarga, dan Good Corporate Governance Terhadap Penghindaran Pajak (Studi pada Perusahaan Manufaktur di Bursa Efek). Jurnal Ilmiah Akuntansi, 7(2). 167-193.

Susanto, L., Yanti, \& Viany. (2018). Faktor-Faktor yang Mempengaruhi Agresivitas Pajak. Jurnal Ekonomi, 5(10). 10-19.

Tiaras, I., \& Wijaya, H. (2015). Pengaruh Likuiditas, Leverage, Manajemen Laba, Komisaris Independen, dan Ukuran Perusahaan Terhadap Agresivitas Pajak. Jurnal Akuntansi, 3(2). 380-397.

Yogiswari, N. K., \& Ramantha, I. W. (2017). Pengaruh Likuiditas dan Corporate Social Responsibility pada Agresivitas Pajak dengan Corporate Governance sebagai Variabel Pemoderasi. E-Jurnal Akuntansi Universitas Udayana, 4(1). 730-759.

Yuliana, I. F. (2018). Likuiditas, Profitabilitas, Leverage, Ukuran Perusahaan, Capital Intensity, dan Inventory Intensity Terhadap Agresivitas Pajak (Studi Empiris pada Perusahaan Manufaktur yang Terdaftar di Bursa Efek Indonesia Tahun 2013-2017). Dinamika Akuntansi, Keuangan, dan Perbankan, 4(6). 105120.

Zemzem, A., \& K, F. (2013). The Effects of Board of Directors Characteristics on Tax Aggressiveness. Research Journal of Finance and Accounting, 6(1). 140-147.

Zulaikha, D. A. (2014). Pengaruh Size, Leverage Profitability, Capital Intensity Ratio, dan Komisaris Independen Terhadap Effective Tax Rates (ETR). Diponegoro Journal of Accounting, 2(1). 1-9. 